\title{
PROGRAM PERCEIVED VALUE AND PROGRAM SATISFACTION INFLUENCES ON STORE LOYALTY Insights from Retail Loyalty Progam
}

\author{
NorAsiah Omar \\ Rosidah Musa \\ MuhamadAzrin Nazri
}

Investigations to determine whether program perceived value could influence program satisfaction, program card loyalty and store loyalty are critical to elucidate the roles and significance of the constructs and advancing management practice. Accordingly, in line with this research direction, this study aims to assess the effects of program perceived value offered by few leading retail superstores and departmental storesin Malaysia on its members' loyalty towards the store. The data set utilized in this study has been obtained via quota sampling technique, where a sample of 153 retail loyalty programs' members was analyzed. An integrative conceptual model was developed and tested using Structural Equation Modeling using AMOS program. The results exemplify that program perceived value is a strong driver of program satisfaction and program card loyalty. Unexpectedly, program perceived value is not a significant predictor of store loyalty but, it has an indirect effect on store loyalty mediated by program satisfaction.

Continuous plea in marketing management is to make marketing instruments more efficient. In recent years introduction of customer relationship marketing instruments is strongly advocated, both in marketing theory and practice. Several researchers (e.g., Berry 1983; Berry and Parasuraman 1991; and Gronroos, 1994) 
Gadjah Mada International Journal of Business, September - December 2007, Vol. 9, No. 3

have changed the focus of a marketing orientation from attracting short-term, discrete transactional customers to retaining long-lasting, intimate customer relationships. In fact Roberts, Varki, Brodie (2003), further suggested that it is best to describe relationship marketing as the formation of "bonds" between the company and the customer. Achieving an effective relationship in a consumer context is considered to be even more challenging than it is in a business-tobusiness context, given the generally more polygamous character of consumers as opposed to business customers (Keng and Ehrenberger 1984; Pressey and Matthews 1998).

Keywords: behavioral loyalty; perceived value; retail loyalty program; relationship marketing; satisfaction

\section{Introduction}

In late eighties and throughout most of the nineties, relationship marketing became a focal point in much of the business-to-business (Dwyer et al. 1987; Morgan and Hunt 1994) and services (Berry 1995) literature. In comparison with manufacturers, retailers have an advantage in establishing enduring relationships with consumers because they are in a better position to detect consumer purchase patterns and apply this knowledge in a cost-efficient way (Sweeney et al. 1999). Moreover, collecting information from the consumer's side of the retailer-consumer relationship is considered an important future research avenue (Sheth and Parvatiyar 1995). Hence, in the past decade there has been many firms (re)adopt a customer focus -often through a formal program ofCustomer Relationship Management (CRM) (Brown 2000; Peppers and Rogers 1997). The recent advances in information technology have provided the tools for marketing managers to create a new generation of CRM tactics.

Accordingly, Bhattacharya(1998) postulates that:

"In the currentera of intense competition and demanding customers, many marketing relationship strategies have been developed and adopted, one such tactic that tthousands of firms have considered, and which many have adopted, is to establish a customer loyalty card program."

In fact, Liebermann (1999) assert that loyalty programs are likely to prove an effective tool within the relationship marketing framework. Accordingly, loyalty programs are defined as the business process of identifying, maintaining, and increasing the yield from best customers through interactive, value-added relationships (Capizzi, Ferguson and Cuthbertson 2004; Omar et al. 2007). Besides that, loyalty programs are used as a means 
to communicate to the customers and the company or/and a means to establish reciprocity between the customer and the company (Kumar and Shah 2004). That is, reward from a loyalty program may generate a feeling of obligatory response from the customer in the form of more business which in turn may lead to more rewards offered from the company and so on. Few researchers noted that loyalty program has become an important strategy and mechanism for retailers to increase revenue growth and has become a key component of customer relationship management (CRM), serving a critical role in developing relationships, stimulating product and service usage, and retaining customers (Kivetz and Simonson 2003). Indeed, the program has become a concentrated effort by retailer to build store traffic, increase basket size and increase frequency which creating deeper relationship ties with its customer base (Allaway et al. 2003).

Generally, the importance of loyalty programs has been recognized in both the managerial and economic modeling literature (e.g., Kim, Shi and Srinivasm 2001). According to Fowler (2004), more than half the U.S. (adult) population currently participates in at least one loyalty program. While, in U.K around 80 percent of U.K. household participate in at least one customer loyalty program. According to Bellizi and Bristol (2004) the use of loyalty programs grew exponentially in the U.S., U.K. and all around the world. According to Reinartz and Kumar (2002), during the year 2000 the top 16 retailers in Europe together spent about \$1 billion on retention/ loyalty initiatives and some supermarket chains even devote a yearly budget of more than $\$ 150$ million to its loyalty programs. It is clear that the phenomenon is not restricted to the U.K., as loyalty programs have been established across Europe and in other parts of the developing countries. Despite the popularity of these programs, little is known about the underlying factors driving consumer behavior relevant to these kinds of relationship programs. Liebermann (1999) and Palmer at al. (2000) studies raise up conflicting evidence concerning the relationship between loyalty program and loyalty. Bellizzi and Bristol (2004) examine the role of loyalty program in creating loyalty find that loyalty program is not associated with loyalty. In addition, findings revealed that 79 percent of customers in casual apparel and 70 percent in grocery say they are always seeking alternatives to their current retailers (The McKinsey Quarterly, 2001). Gaughan(2006) further describe that a blended approach of hard (reward) and soft (recognition) benefits is the optimal way to improve retail loyalty program revenue and to reduce customer attrition. As a result of this worldwide glut of loyalty programs, consumers are becoming more alert than ever, and seek not those programs that offer only a me-too approach to loyalty, but rather those programs that 
bolster their overall value proposition with a sophisticated and differentiated rewards programs.

Based on Capizzi and Ferguson (2006) and Noordhoff et al. (2004) loyalty membership market is in its maturity stage particularly in Europe and U.S.A. Meaning, consumer is in danger of entering prolonged phase of boredom with loyalty programs. In fact, this is one argument against the effectiveness of loyalty programs in the European market (Noordhoff et al. 2004). With static retail markets in the USA and Europe, retailers have targeted Asia where markets are growing twice as fast as at home (Strategic Direction 2005). Accordingly, Noordhoff et al. (2004) pointed that, one advantage in the Asian market is that customers have not had the opportunity to acquire loyalty program fatigue. Moreover, the Asian economic crisis in the late 1990s have turned Asians to be "bargain hunters" who prone to be loyal to retailers offering value for money, particularly in the form of discounts, points and vouchers.

Accordingly, research done by consulting firm Frost and Sullivan revealed that the loyalty program business in Malaysia is currently worth RM2.4 billion, and is projected to grow to RM3.5 billion by 2010 (Ganesan, 2006). Jaya Jusco (Aeon) in Malaysia who stands at the forefront of customer loyalty strategies in the retail sector with flagship J-Card loyalty program currently has nearly 580,000 program members account for an average of 54-
58 percent of their monthly sales (Colloquy 2004). Over the years, the landscape of loyalty programs in Malaysia has changed. It has moved from the use of one program by one outlet to one used by many outlets and now a multifunction program.

Because of the pervasiveness of these types of programs, it is vital to investigate the impact of program perceived value towards program satisfaction and finally its influence towards loyalty. The results of the study will reveal the mechanism by which the loyalty program operates such as whether loyalty program induce loyalty to the program rather than loyalty to the store. In addition, it will also address the issues of whether loyalty to the program leads to loyalty to the store.

Generally, the result from this study will have practical impact to managers, since loyalty programs have emerged as a popular marketing strategy for thousands of firms, including many of the world's biggest and best known firms. The results derived from this paper could offer many potential implications for the retailers that offer loyalty program to its customers. In brief, the research findings could assist the industry managers in formulating effective strategies specifically in its loyalty programs and consequently better utilize these customers for additional marketing support and information resources that help firms to enhance their marketing performance.

The research framework which identifies a six-stage path analytic 
Omar, Muhamad \& Musa-Program Perceived Value and Program Satisfaction Influences on Store Loyalty

Figure 1. Proposed Conceptual Model with Hypothesised Paths

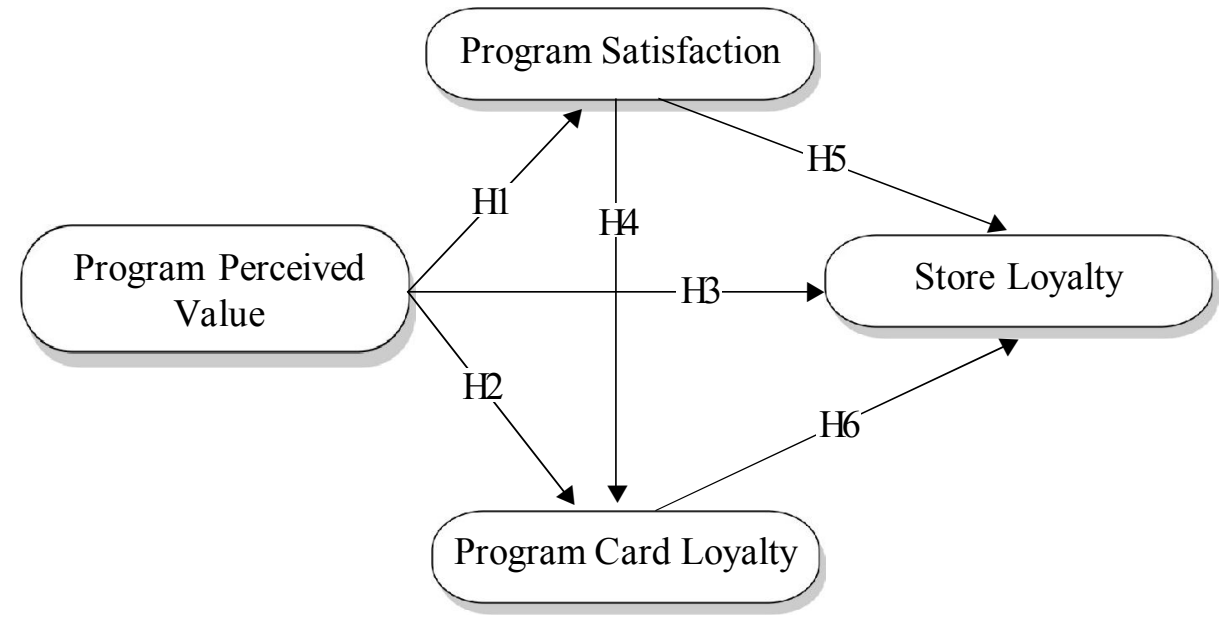

model delineating the factors involved in a sequential model. The study explores the linkages between program perceived value, program satisfaction, program card loyalty and store loyalty among loyalty program's members in a superstores and departmental stores. Figure 1 depicts the integrative research framework among the constructs in a path diagram format. The framework comprises of program perceived value, program satisfaction, program card loyalty and store loyalty. This paper is organized as follows: Section 1 provides the introduction to this research, Section 2 discusses literature review, Section 3 shows research design and method, Section 4 documents research findings and discussion, and eventually, Section 5 provides the limitations, future research and the conclusion.

\section{Literature Review}

Customer relationship marketing is essential for success in today's and tomorrow's retailing. This is particularly revealed in the huge investment in customer relationship Winer 2001). Achieving an effective relationship in a consumer context is considered to be more challenging than it is in a business-to-business context, given the generally more polygamous character of consumers as opposed to business customers (Pressey and Matthews 1998). Today, the usage of loyalty programs as a technique for firms to enhance customer loyalty is seem to be everywhere and become extremely popular among both consumers and firms (Luxton 1998). 
Howard-Brown (1998) found that 31 percent of consumers stated that loyalty and store cards exerted an influence on them. Study by Cigliano et al. (2000) indicated that 53 percent of grocery customers and 21 percent of customers of casual apparel retailers are enrolled in loyalty programs, of which 48 percent and 18 percent of the grocery and apparel customers claimed to spend more than they would otherwise. Another survey also found that nearly half (49 percent) of the program's members pointed out that the programs have influenced on where they decide to spend their retail dollars, with the majority also indicating that they are faithful to the loyalty programs they choose to join.

On the other hand, Mauri (2003) and Yi and Jeon (2003) find that not all subscribes to a loyalty program are in fact card loyal. Result from the study indicated that some of the members use more than one loyalty program; other do not use the program; and most customers seem not to know the mechanics of the reward schemes of loyalty programs (Sharp and Sharp, 1997). Accordingly, Wright and Sparks (1999) indicated 23 percent of the programs studies by them were not used, 13 percent of the programs were not in used in last 3 months of the period taken into consideration and customers tended not to use the program when they paid cash for small amounts of goods/services. Being aware of the ' $l a$ ziness' of customers, retailers often reward their customers for continuous usage of the program. These rewards often take the form of promotional or incentives tied to specific desired behaviors. For example, customers who want to receive the rewards may have to use the program, but also have to follow the retailer's suggestions such as spending a certain amount, buying specific product types, choosing certain brands, visiting the store with a certain frequency or sometimes at specific hours of specific days. The higher is the cardholder's conform to the retailer's demands the higher rewards the customer will receive in return.

Due to the mix results researchers have questioned whether loyalty programs are indeed a manifestation of relationship marketing (Hart et al. 1999). Purist argues that loyalty building 'techniques' are nothing but mere promotional gimmicks and that loyalty is only earned by consistent deliver superior value at every point of contact with customers.

Sheth and Parvatiya (1995) have noted that, marketers are constantly challenged to increase the value of their product/service by improving the product/service benefits, reducing costs through productivity or both. Superior value of product/service represents a significant competitive advantage for the firm in building profits and customer satisfaction (Ulaga and Chacour 2001). Similarly, Mauri (2003)claimed that consumers who decide to be loyal cardholders are firstly intrigued by the absolute value of the rewards targeted at them. Interestingly, Lind and Tyler (1988) indicated that loyalty programs can increase the intrinsic motivation of 
Omar, Muhamad \& Musa-Program Perceived Value and Program Satisfaction Influences on Store Loyalty

participants thus deemphasizing the need for rewards by providing identity-related 'soft' benefits such as ranking and congratulating top members, fostering a sense of community, and treating members as unique, valuable individuals. Many authors have advocated that knowing where value resides from the standpoint of the customer has become critical for managers, because greater level of customer satisfaction lead to greater levels of customer loyalty and retention, positive word-of-mouth, a stronger competitive position, and ultimately, higher market share (Fornell 1992; Bearden and Teel 1983).

\section{Program Perceived Value}

Perceived value is a trade-off between the benefits customers receive in relation to total cost which include the price paid plus other costs associated with the purchase (McDougall and Levesque 2000). In the context of this study, program perceived value is conceptualized as the customer's overall assessment of the loyalty programs towards all the relevant benefits and reward incurred by the program's members. Prevalently, perceived value has been positioned as the pivotal role within the exchange concept of marketing (Eggert and Ulaga 2002). Research reveals that customers are less likely to switch if they better understand the actual economics, time, and energy-saving value of staying in a relationship (Gwinner et al. 1998). In fact Harnett (1998) advocated that, "when retailers satisfy peoplebased needs, they are delivering value which puts theminamuch strongerposition in thelong-term."

O'Malley and Tynan (2000) document that, if the consumers do not perceive value in building relationships with a firm, then they might only engage in a relationship to the extent that a better option is not available elsewhere. Similarly, Dowling and Uncles (1997) claimed that:

“..... loyalty programs must enhance the overall value of the product or service and motivate loyal buyers to make their next purchase."

In order to make a loyalty program effective it must have a structure that motivates customer to view purchases as a sequence of related decisions rather than as independent transactions (Lewis 2004). The structure of the program must be able to give customers an incentive to adopt a dynamic perspective. For example, O'Brien and Jones (1995) suggest that the major factors that customer consider when evaluating programs are the relative value of awards and the likelihood of achieving a reward. In addition, the likelihood of achieving a reward is a function of cumulative buying threshold and time constraints. Hence, the design elements (e.g. rewards, time constraints) combine with individuallevel requirements and preferences will influence the customer's expected benefits of participating in a loyalty program. 
As emphasized by Sirdeshmukh et al. (2002) value a superordinate consumer goal, regulates consumer actions at the level of loyalty intention. Consumers are expected to direct their actions towards achievement of this goal; they will indicate loyalty intentions toward a products or service that can deliver superior value. Similarly, Bolton and Drew (1991) that value is an important determinant of consumers' loyalty intention toward telephone services. Moreover, perceived value plays an important role in the determination of store loyalty; it will increase consumers likelihood of recommending the supplier and reduce the tendency of seeking alternative information (Sirohi et al. 1998). Accordingly, the first, the second and third hypotheses of this study are as follows:

$H$ 1: In the retail loyalty program context, a higher level of program perceived value leads to a higher level of program satisfaction.

H 2: In the retail loyalty programcontext, a higher level of program perceived value leads to a higher level of program card loyalty.

H 3: In the retail loyalty programcontext, a higher level of program perceived value leads to a higher level of store loyalty.

\section{Program Satisfaction}

Lervik and Johnson (2003), and Rust et al. (1995) define customer satisfaction as a cumulative evaluation of a customer's purchase and consump- tion experience to date. The definitions imply customer satisfaction as an overall evaluation based on the total experience with a good or service over time. Therefore, in the current study, the authors specifically established that the consumer experience with the retail loyalty program must occur at least within twelve months prior to data collection. Accordingly, program satisfaction is defined as: program member's affective state as a result of cumulative evaluation of experience with the loyalty program.

Mcllroy and Barnett (2000) express that, an important concept to consider when developing a customer loyalty program is customer satisfaction. Satisfaction is a measure of how a customer's expectations are met while customer loyalty is a measure of how likely a customer is to repurchase and engage in relationship activities. Several prior researchers (e.g., Bolton 1998) find a connection between satisfaction and loyalty. The relevance of satisfaction in gaining loyal customers and generating positive word-of-mouth is largely undisputed (e.g., Anderson and Sullivan 1993; Oliver 1996). Indeed, few researchers identified that satisfaction is one of the factor in determining loyalty (e.g., Anderson, Fornell and Lehmann 1994). In addition, satisfaction has been recognized as a main driver in determining positive word-of -mouth behavior (e.g., File et al. 1994). Hence, based on past literature the fourth and fifth hypotheses of this study are as follows: 
Omar, Muhamad \& Musa-Program Perceived Value and Program Satisfaction Influences on Store Loyalty

H 4: In the retail loyalty program context, a higher level of program satisfaction leads to a higher level of program card loyalty.

$H$ 5: In the retail loyalty program context, a higher level of program satisfaction leads to a higher level of store loyalty.

\section{Loyalty}

Sharp and Sharp (1997) explicitly stated that the effectiveness of relationship marketing efforts should be evaluated in terms of behavioral changes they bring about. As a result, few researchers (e.g., Hennig et al. 1997; and Reichheld 1994) accepted behavioral loyalty as the ultimate relationship outcome.

Some writers, such as Bloemer and Oderkerken-Schroder (2002), and Shoemaker and Lewis (1999) describe loyal behavior as customers who feel so strongly that you (the company) can best meet his or her relevant needs that your (the company's) competition is virtually excluded from the consideration set; these customers buy almost exclusively from you (the company). Accordingly, the current study defines program card loyalty as: a cardholder's drive to continue and maintain a relationship with a retail loyalty program accompanied by the cardholder's willingness to make additional efforts. While, store loyalty is conceptualized as, a high commitment to rebuy or repatronize a preference product or service consistently in the future, despite situational influences and mar- keting efforts which have the potential to cause switching behavior.

Bolton et al. (2000) documents that the goals of a loyalty program is to achieve a higher level of customer retention particularly in profitable segments by providing increased satisfaction and value to certain customers. For example, many supermarket loyalty programs have focused towards heavy users; the justification for these programs is to increase customer satisfaction and loyalty which in turn will have a positive influence on long-term financial performance (Anderson et al. 1994; Reichheld and Sasser 1990).

It has been widely documented that, the store which offered loyalty program to their customers is likely to eenjoy benefits of store loyalty and/or brand loyalty (Lieberman 1999; Noordhoff et al. 2004; Ji and Jeon 2001). A valuable relationship is seen as a 'barrier to entry' mechanism which provides a powerful competitive advantage for a company. Sharp and Sharp (1997) find that have a greater effect on the average purchase frequency than on share-of-customer (Sharp and Sharp 1997). Hence, based on the level of customer participation, most loyalty programs are arranged to ensure that the highest spending members will receive the greatest rewards.

As the most prevailing relationship link is between loyalty program membership and loyalty, it is essential to highlight the mechanism by which the retail loyalty programoperates specifically the mechanism between program card loyalty and store loyalty. It 
is noteworthy to highlight the recent findings by Mauri (2003) in which she discover that the more customers visit a store, the higher the customers will be loyal towards the program. It is believed that members bonding with the program have a concrete potential of enhancing members' patronage with the store. Therefore, it is anticipated that consumers who are loyal towards a loyalty program will display high loyalty towards the store. Inspired by these ideas and findings, the author investigates the hypotheses:

$H$ 6:In the retail loyalty program context, a higher level of program cardloyalty leads to a higher level of store loyalty.

\section{Review of Methodology}

\section{Research Design}

A survey was carried out in the Klang Valley of Malaysia, which was reported to have the highest number of modern retail stores such as supermarkets and hypermarkets (Euromonitor 2004). Moreover, it is also noted that loyalty programs are still in its early days in Southeast Asia with plenty of room for expansion (AcNielsen 2005). The data for this study were collected by using self-administered questionnaires distributed using quota sampling technique by undergraduate marketing students as a part of their "subject pool" requirement. The guidelines for respondent's eligibility were clearly provided to insure a varied sample and to exclude participation that was not eligible (Mick 1996). The population of interest for this study was defined as consumers (over 16 years of age) who a member of any retail loyalty program (superstores and departmental stores) within the last twelve months prior to data collection (June 2006-August 2006) and who live or work within Klang Valley, Malaysia. The survey instrument used a comprehensive set of 17 questions that were directly tied to the four constructs of the study. The interval scale was anchored using a Likert type measurement approach. Five response categories with properties labeling established only for the scale end points from (1) which denotes "strongly disagree," and (5) for "strongly agree." This scale approach was favored in order to maintain the scale interval-level properties (Allen and Rao, 2000). Before conducting the study, the author pre-tested the survey instrument by personally administering it to 10 lecturers to verify the suitability of the terminology used as well as the clarity of the instructions and scales.

Generally, the students were divided into 5 groups and each group was instructed to have more adults to complete the survey. In order to obtain richer insights, the respondents need to join the program for at least a year. This length of membership time was reported to be sufficient to regard respondents as quite experienced, a factor that contributes to the validation of the data (Liebermann 1999). This data collection technique has resulted in 165 respondents, but only 153 were 
Omar, Muhamad \& Musa-Program Perceived Value and Program Satisfaction Influences on Store Loyalty

valid to be used. The ratio of man to womaen in the sample was set at 1:3, based on few studies conducted in Malaysia and many other countries that suggested that women make up a significantly larger percentage of purchasers (Harmon and Hill 2003) compared to men. Amongst the 153 usable questionnaires, 68 (44.4\%) represented cardholders who owned at least 2 loyalty programs and $50(33 \%)$ represented cardholders with one loyalty program. In term of program membership, majority of the cardholders owned their card membership for 2 years and more. This majority represented 97 cardholders $(63 \%)$. All variables in this study were measured by multiitem scales, and operationalized based on previous research, such as Bolton and Drew (1991), Feng (2004), Crosby and Stephens (1987), Musa (2004), Yi and Jeon (2003), and Zeithaml et al. (1996).

\section{Data Analysis Methods}

The measures utilized in this study initially were purified via item-to-total correlation and exploratory factor analyses with varimax rotation. Item which loads 0.50 or greater on one factor and did not have cross-loadings greater than 0.30 on other factors were accepted for further analysis (Rentz et al. 2002). Moreover, parameter estimates of item factor loading and communalities were consulted to identify ways that each sub-scale might improve from an empirical perspective. According to Byrne (2001) to be a good measure of an underlying construct, an item needs to have a significant factor loading and a decent communality. Items which exhibited loading and cross loadings of less than 0.5 were deleted. Moreover, small communalities (relative to other items) were targeted for removal to enhance model parsimony. However, theoretical concerns related to item content were given first priority in model modifications. This initial purification exercise resulted in the deletion of 3 items on the basis of high cross loadings on multiple factors. To assess the instruments, all the items were factor analyzed, and the result revealed that the KaiserMeyer-Olkin Measure of Sampling Adequacy (KMO) presented an index of 0.896, which is considered good for carrying factor analysis. The Bartlett Test of Spericity, a statistical test to determine the presence of correlations among the variables, was also employed in this study, and it was statistical significant. These results indicate the suitability of the factor analysis technique for this study. A four-factor solution was initially extracted with accounted for 66.09 of the total variance explained. Cronbach's alpha which was utilized to test for internal consistency for all dimensions extracted from exploratory analysis, were above the minimum acceptable score of 0.70 (Gerbing and Anderson 1988), ranged from 0.72 to 0.85 (see Table 1 ). This clearly indicates that the scales used in this study were highly reliable (Nunnally 1978). 
Gadjah Mada International Journal of Business, September - December 2007, Vol. 9, No. 3

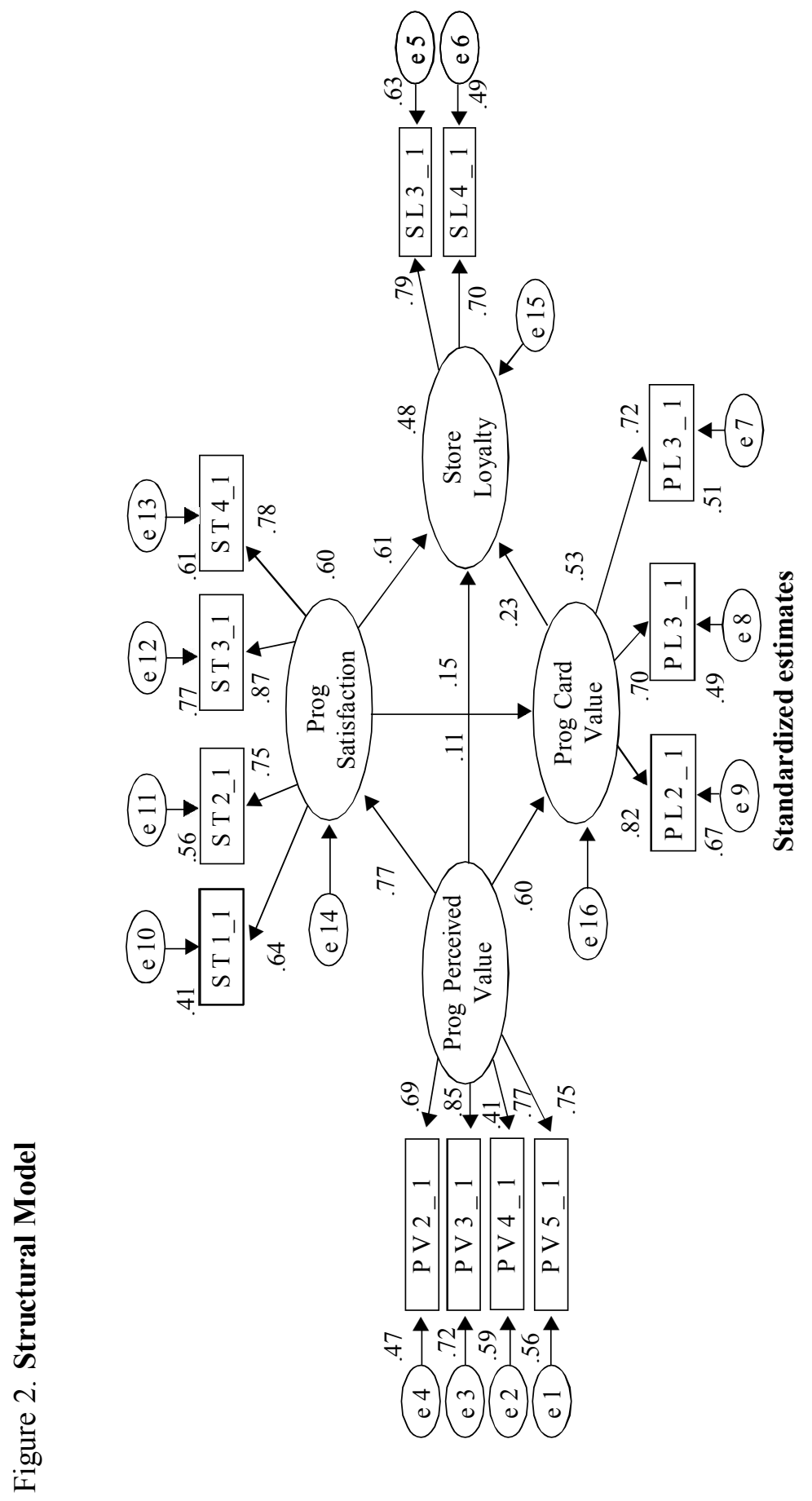


Omar, Muhamad \& Musa-Program Perceived Value and Program Satisfaction Influences on Store Loyalty

The pool of items was further refined using confirmatory factor analysis (via AMOS 6.0 and the maximum likelihood estimation technique). To test the Hypothesized links among the constructs in the framework, Structural Equation Modeling was used and subsequently analyzes the mediating effect of program card loyalty in the satisfaction-store loyalty chain. Table 1 presents the correlation matrix, descriptive statistics, Cronbach's alpha, reliability coefficients, composite reliability, squaremultiple correlation $\left(\mathrm{R}^{2}\right)$, AVE for the measures and sources of items. Figure 2 depicts the structural model.

\section{Reliability and Validity of Measures}

Reliability and validity test are important to standardize the measurement scales, and to demonstrate whether they truly measure what they are supposed to measure. In Structural Equation Modeling (SEM), there are some statistical outputs which can be used to measure the construct reliability. They include square multiple correlations $\mathrm{R}^{2}$ for eachmeasurement item, composite reliability, and variance extracted for each factor. As a rule of thumb measurement variables are reliable when the square multiple correlation $\mathrm{R}^{2}$ of each one is greater than 0.5 (Byrne 2001). Cronbach alpha coefficient, composite reliability and variance extracted were calculated to measure the reliability of each factor, as represented in Table 1. Composite reliability should be greater than 0.7 and variance extracted $(\mathrm{AVE})>0.5$ to indicate reliable factors (Hair et al. 1998). The composite reliability and variance extracted were calculated using Fornell and Larker's (1981) formula. The composite reliability, variance extracted, and Cronbach alpha coefficient values for all critical factors, greatly exceeded the minimum acceptable values. This indicated that the measures were free from error and therefore yielded very consistent results (Zikmund 2003).

Given that the factor structure remained stable, we proceed to perform a confirmatory factor analysis (CFA) using AMOS 6.0 to test the 6 hypothesized relationships among the constructs. Accordingly, the assessment of the model fit in this paper was based on multiple criteria; the normed $X^{2}$ or $X^{2} / d f$ ratio, the Root Mean Square Error of Approximation (RMSEA), the Comparative Fit Index (CFI), TuckerLewis Index (TLI), Normed Fit Index (NFI), Incremental Fit Index (IFI), and the Relative Fit Index (RFI) (Hair et al. 1998; Byrne 2001). Table 2 shows the acceptable fit criteria and the model fit indices values. All of the statistical values of the final measurement model indicated that the model fitted well in representing the data. Ultimately, results for the hypothesized structural paths are reported in Table 3. Standardized coefficient is preferable as it is generally used in multiple regression (de Vaus 2002). Other reasons for using standard coefficients are the variables are on the same scale on measurement, are more easily interpreted and can be easily be converted back to 
Gadjah Mada International Journal of Business, September - December 2007, Vol. 9, No. 3

Table 1. Correlation Matrix

\begin{tabular}{|c|c|c|c|c|c|c|c|c|c|}
\hline Construct & Mean & SD & $\begin{array}{c}\text { Std } \\
\text { Regression } \\
\text { (Loadings) }\end{array}$ & $\begin{array}{c}\text { Critical } \\
\text { Ratio } \\
\text { (t-values) }\end{array}$ & $\mathbf{R}^{2}$ & $\begin{array}{l}\text { Composite } \\
\text { Reliability }\end{array}$ & AVE & $\alpha$ & $\begin{array}{l}\text { Sources of } \\
\text { items of the } \\
\text { Constructs }\end{array}$ \\
\hline $\begin{array}{l}\text { Program } \\
\text { Perceived Value (X1) }\end{array}$ & 3.47 & 0.64 & & & - & 0.90 & 0.70 & 0.85 & $\begin{array}{l}\text { Bolton and } \\
\text { Drew (1991); } \\
\text { Feng (2004) }\end{array}$ \\
\hline $\begin{array}{l}\text { 1. worth the money } \\
\text { (PV2) }\end{array}$ & & & 0.69 & 8.27 & & & & & \\
\hline $\begin{array}{l}\text { 2. getting a good deal } \\
\text { (PV3) }\end{array}$ & & & 0.85 & 10.22 & & & & & \\
\hline 3. economical (PV4) & & & 0.77 & 9.28 & & & & & \\
\hline 4. reasonable (PV5) & & & 0.75 & - & & & & & \\
\hline $\begin{array}{l}\text { Program Satisfaction } \\
\text { (X2) }\end{array}$ & 3.46 & 0.62 & & & 0.60 & 0.91 & 0.72 & 0.84 & $\begin{array}{l}\text { Crosby and } \\
\text { Stephens } \\
(1987)\end{array}$ \\
\hline 1. very satisfied (STI) & & & 0.64 & - & & & & & \\
\hline 2. right decision (ST2) & & & 0.75 & 7.72 & & & & & \\
\hline $\begin{array}{l}\text { 3. pleased experience } \\
\text { (ST3) }\end{array}$ & & & 0.88 & 8.60 & & & & & \\
\hline $\begin{array}{l}\text { 4. satisfies my needs } \\
\text { (ST4) }\end{array}$ & & & 0.78 & 8.00 & & & & & \\
\hline $\begin{array}{l}\text { Program Card Loyalty } \\
\text { (X3) }\end{array}$ & 3.39 & 0.65 & & & 0.53 & 0.87 & 0.62 & 0.79 & $\begin{array}{l}\text { Yi and Jeon } \\
(2003)\end{array}$ \\
\hline 1. like the program (PL 1) & & & 0.82 & 8.46 & & & & & \\
\hline 2. strong preference (PL2) & & & 0.70 & 7.61 & & & & & \\
\hline $\begin{array}{l}\text { 3. recommend the } \\
\text { program (PL3) }\end{array}$ & & & 0.72 & - & & & & & \\
\hline Store Loyalty (X4) & 3.45 & 0.60 & & & 0.48 & 0.85 & 0.73 & 0.72 & $\begin{array}{l}\text { Zeithamal } \\
\text { et al. (1996) }\end{array}$ \\
\hline $\begin{array}{l}\text { 1. recommend the store } \\
\text { (SL3) }\end{array}$ & & & 0.79 & 6.37 & & & & & \\
\hline $\begin{array}{l}\text { 2. strong store preference } \\
\text { (SL4) }\end{array}$ & & & 0.70 & - & & & & & \\
\hline
\end{tabular}


Omar, Muhamad \& Musa-Program Perceived Value and Program Satisfaction Influences on Store Loyalty

Table 2. Goodness of Fit Indices for Model

\begin{tabular}{|c|c|c|}
\hline Goodness of fit indices & Fit Criteria & Model \\
\hline$X^{2}$ & & 73.754 \\
\hline $\mathrm{df}$ & & 59 \\
\hline $\mathrm{p}$ & & 0.094 \\
\hline$X^{2} / \mathrm{df}$ & $=3$ & 1.25 \\
\hline RMSEA & $=0.08$ & 0.041 \\
\hline CFI & $=0.9$ & 0.984 \\
\hline TLI & $=0.9$ & 0.979 \\
\hline NFI & $=0.9$ & 0.926 \\
\hline IFI & $=0.9$ & 0.984 \\
\hline RFI & $=0.9$ & 0.902 \\
\hline
\end{tabular}

Adapted from Hair et al. (1998) and Byrne (2001)

Table 3. Results of the Hypotheses Tested

\begin{tabular}{|c|c|c|c|c|}
\hline \multirow[b]{2}{*}{$\mathrm{H} 1$} & \multirow{2}{*}{$\begin{array}{l}\quad \text { Hypothesised Path } \\
\text { Program Perceived Value } \\
\rightarrow \text { Program Satisfaction }\end{array}$} & $\begin{array}{l}\text { Standardized } \\
\text { Coefficient }\end{array}$ & $\begin{array}{l}\text { Critical Ratio } \\
\text { (t-value) }\end{array}$ & \multirow{2}{*}{$\begin{array}{c}\text { Results } \\
\text { Supported }\end{array}$} \\
\hline & & 0.772 & $6.579 * * * *$ & \\
\hline $\mathrm{H} 2 \mathrm{P}$ & $\begin{array}{l}\text { Program Perceived Value } \\
\rightarrow \text { Program Card Loyalty }\end{array}$ & 0.605 & $3.819 * * * *$ & Supported \\
\hline $\mathrm{H} 3 \mathrm{P}$ & $\begin{array}{l}\text { Program Perceived Value } \\
\rightarrow \text { Store Loyalty }\end{array}$ & -0.109 & -0.563 & Not Supported \\
\hline H4 $\mathrm{F}$ & $\begin{array}{l}\text { Program Satisfaction } \\
\rightarrow \text { Program Card Loyalty }\end{array}$ & 0.153 & 1.062 & Not Supported \\
\hline H5 $\mathrm{P}$ & $\begin{array}{l}\text { Program Satisfaction } \\
\rightarrow \text { Store Loyalty }\end{array}$ & 0.614 & $3.378 * * * *$ & Supported \\
\hline H6 P & $\begin{array}{l}\text { Program Card Loyalty } \\
\rightarrow \text { Store Loyalty }\end{array}$ & 0.234 & 1.526 & Not Supported \\
\hline Note: & \multicolumn{4}{|c|}{$\begin{array}{l}* * * * \text { Significant at } \mathrm{p}<0.001(\mathrm{t}> \pm 3.29) \\
* * * \text { Significant at } \mathrm{p}<0.01(\mathrm{t}>2.57) \\
{ }^{a} \text { Non-significant }\end{array}$} \\
\hline
\end{tabular}


the raw scale metric (Schumacker and Lomax 2004).

\section{Discussion}

It is worthwhile to highlight that in this study program perceived value and program satisfaction were incorporated in the model. This allowed the authors to examine, test and ultimately generate knowledge on the effects of these constructs on the formation of loyalty toward the program and loyalty toward the store. As highlighted in Table 3, the current study has found strong empirical support (of the hypothesized path of perceived value and program satisfaction as well as program satisfaction and store loyalty. In essence, this findings offer empirical evidence the cardholders that found the program valuable are likely to be satisfied with the program and engaged in behaviors targeted in enhancing the relationship such as loyal to the store. These findings clearly in line with prior studies (e.g. Ball et al. 2006; Grace and O'Cass-2005) that revealed, perceived value is positively related to satisfaction. In fact, recent findings in the tourism and hospitality research, revealed that satisfaction as a consequence of perceived value (Spiteri and Dion 2004).

However, it is important to note that the new linkage which was hypothesized in the present study, program perceived value-store loyalty was found to be insignificant. This finding sharply contradicts with the empirical evidence provided by Lin and Wang
(2006) and Harris and Goode (2004) that perceived value and loyalty are positively related. It is reasonable to speculate that the proposed link was not significant because in the current study program perceived value was conceptualized solely from the economic and rational view. Hence, it would be more fruitful for future research to capture the concept of value from the multidimensional elements specifically from the loyalty program context. Besides that, upon examination of the descriptive findings of respondents' membership duration, it was unveiled that the majority of respondents were experienced cardholders. As noted by prior scholars such as Day (2002), that the perceptions of value sometime change over time largely because of greater experience with the category or brand. Therefore, this implies that economic value is not always an important element for cardholders when evaluating loyalty towards the program, particularly, for experienced cardholders. Hence, more research is needed to capture the influence of membership duration towards the evaluation of program perceived value.

Besides that, it is also important to note that in this study two relationship outcomes, 'program card loyalty' and 'store loyalty' were introduced and examined in the loyalty program context as suggested by few researchers (see Magi 2003; Yi and Jeon 2003). This allowed the authors to examine, test and ultimately generate knowl- 
Omar, Muhamad \& Musa-Program Perceived Value and Program Satisfaction Influences on Store Loyalty

edge on the formation of store loyalty among program members. Interestingly, the research findings demonstrate that program satisfaction is the strongest driver of store loyalty (see Table 3). Apparently, the research results indicate that program perceived value and program card loyalty are not significantly related to store loyalty. Thus, the results elucidate that program satisfaction is the sole determinant of store loyalty.

Clearly, this finding lends support to the notion that loyalty program that is valuable can consistently produce positive outcomes to cardholder such as satisfaction towards the program which indirectly link to store loyalty. Ignoring perceived value in a loyalty program experience may cause lowered satisfaction and reduced loyalty. This is consistent with the views of several other researchers (Chiu et al. 2005; Gallarza and Saura 2006) that satisfaction is the behavioral consequence of perceived value, loyalty attitude being the final outcome. Consequently, this implies that program perceived value is not a predictor of store loyalty however, program satisfaction help to mediate the link between program perceived value and store loyalty. These findings seem plausible both in a research and managerial context: managers might assume that the level of cardholder's loyalty towards the store comes from a higher level of program satisfaction.

\section{Research Limitation and Future Directions}

This study has several limitations that should be considered in an interpretation of the results. A major criticism of the study concerned external validity, as the respondents were not selected randomly, and may not be an accurate representation of the population of loyalty programmembers. However, it should be noted that the profiles of the respondents' (gender and age) are consistent with the existing literature (see Harmon and Hill 2003). On this basis, the results and interpretations may be generalizzeable, specifically with regard to retail loyalty program context in Malaysia and other South-East Asian countries. A second pertinent weakness concerns the crosssectional research design employed. Certainly, longitudinal research is required to fully capture the dynamic nature of customer post-consumption evaluation. Obviously, efforts to test the present model through sagacious longitudinal research would require an enormous amount of sustained cooperation by consumers serving as key informants over time. Next in the current research, reflective-indicators measurement model were used for all the research constructs. To some extent, however, this choice is seem appropriate since the reflective view are widely utilized in the psychological and management science, while the 
Gadjah Mada International Journal of Business, September - December 2007, Vol. 9, No. 3

formative view is common in economics and sociology (Coltman, Devinney, Midgley and Venaik 2008). However, future studies may utilize formative measurement model to investigate how these different views of flow construct could lead to different parameter estimates and conclusions of the same research question with the same data set.

Another weakness concerns with the number of limited aspects is included in the study. Hence, it is suggested to include other aspects to be explored and investigated as well. For example, it may be fruitful for future research to assess whether the type of involvement (high and low involvement) or perception of fairness may have different impact in the proposed model. It may be fruitful for future research to replicate and validate all parts of the current model, in order to determine the robustness of the findings. This research direction appears to be potentially fertile as loyalty program is considered as an important retention strategy and mechanism for retailers to increase revenue growth. In addition, the current model might be extended usefully in future research work through the inclusion of the multidimensional elements of value specifically from the loyalty program context.

\section{Conclusion}

In conclusion, the findings of this study enable us to clarify the structural relationships among core constructs as postulated in the relationship marketing literature. Importantly, the major findings of this study enhance the understanding of the interrelationship among the constructs which were incorporated in the hypothesized model. It is believed that the new findings drawn by the current study will be relevant to the advancement of relationship marketing theory particularly in the customers' retention strategy namely the retail loyalty program. In essence, this study has advanced the understanding of the relationship between program perceived value and relationship outcomes such as store loyalty among loyalty program members.

\section{References}

ACNielsen. 2005. Asia Pacific Retail and Shopper Trends 2005.

Allaway, A. W, D. Berkowitz, and G. D'Souza. 2003. Spatial diffusion of a new loyalty program through a retail market. Journal of Retailing 79 (3): 137-142.

Allen, D. R., and T. R. Roa. 2000. Analysis of Customer Satisfaction Data: A Comprehensive Guide to Multivariate Statistical Analysis in Customer Satisfaction, Loyalty, and Service Quality Research. Milwaukee. Wis: ASQ Quality Press.

Anderson, E. W., and M. W. Sullivan. 1993. The antecedents and consequences of customer satisfaction for firms. Marketing Science 12: 125-143. 
Omar, Muhamad \& Musa-Program Perceived Value and Program Satisfaction Influences on Store Loyalty

Anderson, J.C., C. Fornell, and D. R. Lehmann. 1994. Customer satisfaction, market share and profitability: Findings from Sweden. Journal of Marketing 58 (July): 53-66.

Ball, D., P., S. Coelho, and M. J. Vilares. 2006. Service personalization and loyalty. Journal of Service Marketing 20 (6): 391-403.

Bearden, W. O., and J. E. Teel. 1983. Selected determinants of consumer satisfaction and complaint reports. Journal of Marketing Research 20 (1): 21-28.

Bellizi, J. A., and T. Bristol. 2004. An assessment of supermarket loyalty cards in one major US market. Journal of Consumer Marketing 21 (2): 144-154.

Berry, L. L. 1995. Relationship marketing of services: Growing interest, emerging perspectives. Journal of Academy of Marketing Science 23 (4): 236-245.

Bhattacharya, C. B. 1998. When customers are members: Customer retention in paid membership context. Journal of Academy of Marketing Science 26 (1): 31-44.

Bloemer, J., and G. Odekerken-Schroder. 2002. Store Satisfaction and store loyalty explained by customer and store related factors. Journal of Consumer Satisfaction, Dissatisfaction, and Complaining Behaviour 15: 68-80.

Boedeker, M.ika. 1997. Relationship marketing and regular customer cards daily product retailing in Finland. Marketing Intelligence and Planning 15 (6):249-257.

Bolton, R. 1998. A dynamic model of the duration of the customer's relationship with a continuous service provider: The role of satisfaction. Marketing Science 17 (1): 4565.

Bolton, R. N, and J. H. Drew. 1991. A multistage model of customers' assessment of service quality and value. Journal of Consumer Research 17 (March): 375-384.

Bolton, R. N., P. K. Kannan, and M. Bramlett. 2000. Implications of loyalty program membership and service experiences for customer retention and value. Journal of Academy of Marketing Science 28 (Winter): 95-108.

Brown, J. 2000. The customer EXPRESS. Computing Canada 26 (20): 23.

Buttle, F. 2004. Customer Relationship Management: Concepts and Tools. Elsevier Butterworth Heinemann.

Byrne, B. M. 2001. Structural Equation Modeling with AMOS: Basic Concepts, Applications and Programming. New Jersey: Lawrence Erlbaum Associates Publishers.

Capizzi, M, R Ferguson, and R Cuthbertson. 2004. Loyalty trends for the 21st century. Journal of Targeting, Measurement and Analysis for Marketing 12 (3):199-212.

Capizzi, M. T., and R. Ferguson. 2006. Loyalty trends for the 21 st century. Review of Reviewed Item (April 22). http://www.colloquy.com/reports/TrendTalk.asp.

Capizzi, M., R. Ferguson, and R. Cuthbertson. 2004. Loyalty trends for the 21 st century. Journal of Targeting, Measurement and Analysis for Marketing 12 (3): 199-212.

Chiu, C. M., M. H. Hsu, S. Y. Sun, T. C. Lin and P. C. Sun. (2005). Usability, quality, value and e-learning continuance decisions. Computer and Education 45: 399-416.

Cigliano, J., M. Georgiadi, D. Pleasance, and S. Whalley. 2000. The Price of Loyalty. Mckinsey Quarterly 4: 68-77. 
Gadjah Mada International Journal of Business, September - December 2007, Vol. 9, No. 3

Colloquy. 2004. Malaysia: Hypermarket loyalty program is best in class. Reviewed Item. http://www.colloquy.com.

Coltman, T., T. M. Devinney, D. F. Midgley, and S. Venaik. 2008. Formative versus reflective measurement models: Two applications of formative measurement. Journal of Business Research (Accepted January).

Crosby, L. A., and N. J.-Stephens. 1987. Effects of relationship marketing on satisfaction, retention and prices in the life insurance industry. Journal of Marketing Research 24 (Nov): 404-411.

Day, E. 2002. The role of value in consumer satisfaction. Journal of Consumer Satisfaction, Dissatisfaction and Complaint Behavior 15: 1-16.

de Vaus, D. 2002. Analyzing Social Science Data. Thousand Oaks: Sage Publications.

Cuthbertson, R. 1998. Loyalty card schemes in retailing across Europe. European Retail Digest 20:5-7.

Dabholkar, P. A., D. I. Thorpe, and J. O. Rentz. 1996. A measure of service quality for retail stores: Scale development and validation. Journal of the Academy of Marketing Science 24 (1): 3-16.

Dowling, G. R., and M. Uncles. 1997. Do customer loyalty programs really work? Sloan Management Review 38 (4): 71-82.

Duffy, D. L. 1998. Customer loyalty strategies. Journal of Consumer Marketing 15 (5):435-448.

Dwyer, F. R., P. H. Schurr, and S. Oh. 1987. Developing buyer and seller relationships. Journal of Marketing 51: 11-27.

Eggert, A., and W. Ulaga. 2002. Customer perceived value: A substitute for satisfaction in business markets? Journal of Business and Industrial Marketing 17 (2/3): 107118.

Euromonitor International. 2004. Retailing in Malaysia.

Feng, R. 2004. Member segmentation and value network of a paid travel club: A perspective of relationship marketing. Unpublished PhD Thesis. Purdue University, West Lafayette, IN.

File, K. M., D. S.P. Cermak, and R. A. Prince. 1994. Word-of-mouth effects in professional services buyer behavior. Service Industries Journal 14 (3): 301-314.

Fornell, C. 1992. A national customer satisfaction barometer: The Swedish experience. Journal of Marketing 56: 6-21.

Fornell, C., and D. F. Larcker. 1981. Evaluating structural equation models with unobservable variables and measurement error. Journal of Marketing Research XVIII (Feb): 39-50.

Fowler, M. 2004. When it comes to customer loyalty, it's all about relevance. CRM Buyer. Available from http://www.crmbuyer.com/story/35413.html.

Gallarza, M. G., and R. G. Saura. 2006. Value dimensions, perceived value, satisfaction and loyalty: An investigation of university students' travel behaviour. Tourism Management 27(3): 437-452. 
Omar, Muhamad \& Musa-Program Perceived Value and Program Satisfaction Influences on Store Loyalty

Ganesan, V. 2006. Rich pickings with loyalty cards. New Straits Times (May 2): 40.

Gaughan, T. 2006. Card loyalty: The pursuit of the best rewards blend. Cards and Payments: 50-51.

Gerbing, W., and J. C. Anderson. 1988. An update paradigm for scale development incorporating unidimensionality and its assessment. Journal of Marketing Research 22: 11-19.

Grace, D, and A. O'Cass. 2005. An examination of the antecedents of repatronage intentions across different retail store formats. Journal of Retailing and Consumer Services 12: 227-243.

Gronroos, C. 1990. Service management and Marketing: Managing the Moments of Trust in Service Competition. Lexington, MA: Lexington Books.

Gwinner, K. P., D. D. Gremler, and M. J. Bitner. 1998. Relational benefits in services industries: The customer's perspective. Journal of Academy of Marketing Science 26 (2): 101-114.

Hair, F. J., R. E. Anderson, R. L. Tatham, and W. C. Black. 1998. Multivariate Data Analysis. London: Prentice-Hall International Inc.

Harmon, S. K., and J. C. Hill. 2003. Gender and Coupon Use. Journal of Product and Brand Management 12 (3): 166-179.

Harnett, M. 1998. Shopper needs must be priority. Discount Store News: 21-22.

Harris, L. C., and M. M. H. Goode. The four levels of loyalty and the pivotal role of trust: A study of online service dynamics. Journal of Retailing 80 (2): 139-158.

Hart, S., A. Smith, L. Sparks, and N. Tzokas. 1999. Are loyalty card schemes a manifestation of relationship marketing? Journal of Marketing Management 15: 541-562.

Hennig-Thurau, T., and A. Klee. 1997. The impact of customer satisfaction and relationship quality on customer retention - A critical reassessment and model development. Psychology and Marketing 14 (December): 737-765.

Howard-Brown, J. 1998. The impact of direct mail on consumer loyalty. Journal of Targeting, Measurement and Analysis for Marketing 6 (3): 247-257.

Johnson, M. D., and C. Fornell. 1991. A Framework for comparing customer satisfaction across individuals and product categories. Journal of Economic Psychology 12 (2): 267-286.

Kivetz, R., and I. Simonson. 2003. The idiosyncratic fit heuristic: Effort advantage as a determinant of consumer response to loyalty programs. Journal of Marketing Research 40 (4): 454-467.

Keng, K. A., and A.S.C. Ehrenberger. 1984. Pattern of store choice. Journal of Marketing Research 21 (4):399-409.

Kim, B., M. Shi, and K. Srinivasan. 2001. Rewards program and tacit price collusion. Marketing Science 20 (Spring): 99-120.

Kumar, V., and D. Shah. 2004. Building and sustaining profitable customer loyalty for the 21 st century. Journal of Retailing 80: 317-330. 
Gadjah Mada International Journal of Business, September - December 2007, Vol. 9, No. 3

Lervik, L., and M. D. Johnson. 2003. Service equity, satisfaction and loyalty: From transaction-specific to cumulative evaluation. Journal of Service Research 5: 184195.

Kivetz, R., and I. Simonson. 2003. The idiosyncratic fit heuristic: effort advantage as a determinant of consumer response to loyalty programs. Journal of Marketing ReserachResearch 40 (Nov):454-467.

Knox, S. D., and D. W Walker. 2001. Measuring and managing brand loyalty. Journal of Strategic Marketing 9:111-128.

Lewis, M. 2004. The influence of loyalty programs and short-term promotions on customer retention. Journal of Marketing Research XVI (Aug): 281-292.

Liebermann, Y. 1999. Membership clubs as a tool for enhancing buyers' patronage. Journal of Business Research 45: 291-297.

Lin, H. H., and Y. S. Wang. 2006. An examination of the determinants of customer loyalty in mobile commerce contexts. Information \& Management 43 (April): 271-282.

Lind, E. A. and T. R. Tyler. 1988. The Social Psychology of Procedural Justice. New York: Plenum Press

Luxton, R. 1998. Understanding and assessing the loyalty activities of organisations. Journal of Targeting, Measurement and Analysis for Marketing 6 (4): 352-358.

Mauri, C. 2003. Card loyalty: A new emerging issue in grocery retailing. Journal of Retailing and Consumer Services 10: 13-25.

McDougall, H. G. G., and T. Levesque. 2000. Customer satisfaction with services: Perceived value into equation. Journal of Services Marketing 14 (5): 392-410.

Mcllroy, A., and S. Barnett. 2000. Building customer relationships: Do discount cards work? Managing Service Quality 10 (6): 347-355.

Mick, D. G. 1996. Are studies of dark side variables confounded by socially desirable responding: The case of materialism. Journal of Consumer Research 23 (September): 106-119.

Morgan, R. M., and S.D. Hunt. 1994. The commitment-trust theory of relationship marketing. Journal of Marketing 58 (3): 20-38.

Musa, R. 2004. Modelling customer satisfaction and consequences in the direct sales industry: Az consumption systems approach. Unpublished PhD Thesis. University of Wales, Cardiff.

Musa, R., N.A. Omar, and M. -Mustapha. 2007. Explaining the moderating effects of membership duration in the retail loyalty program: A multi group's causal analysis approach. Paper read at INCOMaR 2007. Malaysia.

Nobel, S. M., and J. Phillips. 2004. Rrelationship hindrance: Why would consumers not want a relationship with a retailer? Journal of Retailing 80:289-303.

Noordhoff, C., P. Pauwels, and G. Odekerken-Schröder. 2004. The effect of customer card programs: A comparative study in Singapore and The Netherlands. International Journal of Service Industry Management 15 (4): 351-364.

Nunnally, I. 1978. Psychometric theory. McGraw Hill. 
O'Brien, L., and C. Jones. 1995. Do rewards really create loyalty? Harvard Business Review 73 (May-June): 75-82.

Oliver, R. L. 1996. Satisfaction: A behavioral perspective on the consumer evaluation in product usage. Journal of Business Research 13: 235-246.

Omar, N.A., R. Musa, and F. Hassan. -2007. The roles of member relationship proneness (MRP) and program relationship orientation (PRO) in creating store loyalty: Evidence from retail Loyalty Programs in Malaysia. Paper read at INCOMaR 2007. Malaysia.

O'Malley, L., and C. Tynan. 2000. Relationship marketing in consumer markets rhetoric or reality? European Journal of Marketing 34 (7): 797-805.

Palmer, A., U. Mcmahon-Beattie, and R. Beggs. 2000. Influences on loyalty program effectiveness: A conceptual framework and case study investigation. Journal of Strategic Marketing 8 (1): 47-66.

Passingham, J. 1998. Grocery retailing and the loyalty card. Journal of Market Research Society 40 (1):55-63.

Peppers, D., and M. Rogers. 1997. Enterprise One to One: Ttools for Competing in the Interactive Age. New York: Currency Doubleday.

Pressey, A., and B. Mathews. 1998. Relationship marketing and retailing: Comfortable bedfellows? International Journal of Customer Relationships Management 1 (1): 39-52.

Reichheld, F. F. 1994. Loyalty and the Renaissance of Marketing. Marketing Management 2 (4): 10-20.

Reichheld, F. F., and W.E.J. Sasser. 1990. Zero Defections: Quality comes to services. Harvard Business Review (Sept/Oct): 105-111.

Reinartz, W. J., and V. Kumar. 2002. The mismanagement of customer loyalty. Harvard Business Review 80 (7): 86.

Rentz, O. J., C. D. Shepherd, A. Tashchian, P. A. Dabholkar, and R. T. Ladd. 2002. A measure of selling skill: Scale development and validation. Journal of Personal Selling and Sales Management 20 (2): 89-98.

Rust, R. T., A. J. Zahorik and T. L. Keiningham. 1995. Return on quality(ROQ): Making service quality financially accountable. Journal of Marketing 59 (2): 58-70.

Schumacker, R. E., and R. G. Lomax. 2004. A beginner's Guide to Structural Equation Modelling ( $2^{\text {nd }}$ ed.). London: Lawrence Erlbaum Associates Publisher.

Sharp, B., and A. Sharp. 1997. Loyalty programs and their impact on repeat-purchase loyalty patterns. International Journal of Research in Marketing 14 (5): 473-486.

Sheth, J. N., and A. Parvatiyar. 1995. Relationship marketing in customer markets: Antecedents and consequences. Journal of the Academy of Marketing Science 23 (4): 255-271.

Shoemaker, S., and R. C. Lewis. 1999. Customer Loyalty: The future of hospitality marketing. International Journal of Hospitality Management 18 (345-370). 
Gadjah Mada International Journal of Business, September - December 2007, Vol. 9, No. 3

Sinha, I., and W. S. DeSarbo. 1998. An Integrated approach toward the spatial modeling of perceived customer value. Journal of Marketing Research 35 (May):236-249.

Sirdeshmukh, D., J. Singh, and B. Sabol. 2002. Consumer trust, value, and loyalty in relational exchanges. Journal of Marketing 66 (Jan): 15-37.

Sirohi, N., E. W. Mc Laughlin, and D. R. Wittink. 1998. A model of customer perceptions and store loyalty intentions for a supermarket retailer. Journal of Retailing 74 (2): 223-245.

Strategic Direction. 2005. Loyalty Cards and Customer Behaviour: Has the Loyalty Card has Its Day in European Retailing?: 18-20.

Sweeney, J. C., G. N. Soutar, and L. W. Johnson. 1999. The role of perceived risk in the quality-value relationship: A study in a retail environment. Journal of Retailing 75 (1): 77-105.

The McKinsey Quarterly. 2001. The price of loyalty marketing power Inc. Available from http://www.marketingpower.com/content1058.php.

Ulaga, W., and S. Chacour. 2001. Measuring customer perceived value in business markets: A prerequisite for marketing strategy development and implementation Industrial Marketing Management 30: 525-540.

Winer, R. S. 2001. A framework for customer relationship management. California Management Review 43 (4): 89-105.

Wright, C., and L. Sparks. 1999. Loyalty saturation in retailing: Exploring the end of retail loyalty cards? International Journal of Retail and Distribution Management 27 (10): 429-439.

Yi, Y., and H. Jeon. 2003. Effects of loyalty programs on value perception, program loyalty and brand loyalty. Journal of the Academy of Marketing Science 31 (3): 229240.

Zeithaml, V. A., L. L. Berry, and A. Parasuraman. 1996. The behavioural consequences of service quality. Journal of Marketing 2: 31-46.

Zeithaml, V.A. 1988. Consumer perception of price, quality and value: A means-end model and synthesis of evidence. Journal of Marketing 52 (July): 2-22.

Zikmund, W. G. 2003. Business Research Methods ( $7^{\text {th }}$ ed.). Thomson, South-Western 